MATH DIDACTIC: JURNAL PENDIDIKAN MATEMATIKA

Volume 4 Nomor 3, September - Desember 2018, halaman 202 - 209

Tersedia Daring pada http://jurnal.stkipbjm.ac.id/index.php/math

\title{
ANALISIS KEMAMPUAN GURU DALAM MENGGUNAKAN ALAT PERAGA MATEMATIKA DI SMP NEGERI 5 LANGSA
}

\section{ANAL YSIS OF TEACHER CAPABILITY IN USING MATH TEACHING AIDS IN JUNIOR HIGH SCHOOL 5 LANGSA}

\author{
Cut Intan Salasiyah, Muhammad Zaki \\ Prodi Pendidikan Matematika FTK UIN Ar-Raniry, Prodi Pendidikan Matematika FKIP Universitas Samudra \\ cintasa@yahoo.co.id, acutzaki@unsam.ac.id
}

\begin{abstract}
Abstrak: Tujuan penelitian ini untuk mengetahui kemampuan guru dalam menggunakan alat peraga di SMP Negeri 5 Langsa. Sumber data dalam penelitian ini adalah guru matematika SMP Negeri 5 Langsa dan alat peraga. Sumber data digali dengan menggunakan teknik wawancara dan observasi aktivitas guru terkait penggunaan alat peraga yang terintegrasi dalam pembelajaran. Penelitian ini adalah penelitian deskriptif dengan pendekatan kualitatif. Berdasarkan analisis data diperoleh informasi bahwa kemampuan guru menggunakan alat peraga belum optimal. Analisis wawancara dan observasi diperoleh informasi aktivitas guru yang terkait penggunaan alat peraga matematika tidak sampai pada konsep atau rumus matematika yang dipelajari.
\end{abstract}

Kata Kunci: Kemampuan Guru, Alat Peraga Matematika

\begin{abstract}
The purpose of this study was to determine the ability of teachers to use teaching aids in SMP Negeri 5 Langsa. The source of the data in this study were mathematics teachers at SMP Negeri 5 Langsa and teaching aids. Data sources are explored using interview techniques and observation of teacher activities related to the use of teaching aids that are integrated in learning. This research is a descriptive study with a qualitative approach. Based on data analysis obtained information that the ability of teachers to use teaching aids is not optimal. Analysis of interviews and observations obtained information on teacher activities related to the use of mathematics teaching aids do not arrive at the concepts or mathematical formulas learned.
\end{abstract}

Keywords: Teacher's Ability, Mathematics Teaching Aids

Cara Sitasi: Salasiyah, C.I. \& Zaki, M. (2018). Analisis kemampuan guru dalam menggunakan alat peraga matematika di SMP Negeri 5 Langsa. Math Didactic: Jurnal Pendidikan Matematika, 4(3), 202-209. 
Matematika merupakan bidang studi atau mata pelajaran yang telah dipelajari oleh siswa dari jenjang pendidikan sekolah dasar sampai sekolah menengah atas. Namun matematika masih menjadi mata pelajaran yang sulit bagi banyak siswa. Belajar matematika momok yang menakutkan bagi siswa. (Muijs dan Reynolds, 2005, hal. 212) mencatat "mathematics is commonly seen as one of the most difficult subjects by pupils and adults alike". Matematika dipandang sebagai pelajaran yang paling sulit oleh anak-anak maupun orang dewasa. (Faux, 2007, hal. 2) juga menulis "mathematics has always been a difficult subject, both for the teacher and the taught". Matematika selalu menjadi pelajaran yang sulit baik untuk guru maupun untuk mengajar.

Menurut (Pujiati, 2004, hal. 1) objek matematika adalah benda pikiran yang sifatnya abstrak dan tidak dapat diamati dengan pancaindra. Karena itu wajar apabila matematika tidak mudah dipahami oleh kebanyakan siswa. Apalagi bagi siswa usia sekolah dasar yang secara teoritis perkembangan intelektualnya masih berada pada tahap operasional konkret akan mengalami kesulitan untuk memahami ide-ide yang abstrak apabila ide-ide yang abstrak itu tidak dimanipulasi ke dalam bentuk konkret. Hal itu dimungkinkan karena pada usia sekolah dasar daya abstraksi anak masih sangat lemah. Begitu juga dengan siswa sekolah menengah pertama dimana siswa mengalami masa transisi dari taraf berpikir konkret ke abstrak.

Meskipun demikian, matematika pada dasarnya adalah ilmu yang mendasari ilmu lainnya dan sangat erat kaitannya dengan kehidupan sehari-hari, oleh sebab itu mau atau tidak mau setiap siswa tentu harus mempelajari matematika. Kesulitan matematika yang dirasakan oleh siswa tersebut harus cepat diatasi agar setiap siswa mampu mengatasi setiap permasalahan yang dihadapi dengan sebaik mungkin. Salah satu alternatifnya adalah dengan menggunakan alat peraga yang diintegrasikan dalam pembelajaran.

Dalam upaya mengkonkretkan hal-hal yang abstrak itu perlu adanya alat peraga dalam pembelajaran matematika. Menurut (Pujiati, 2004, hal. 3) alat peraga dapat menurunkan keabstrakan konsep-konsep matematika sehingga lebih mudah dimaknai. Selain itu, menurut (Ruseffendi, 1992, hal. 140) dengan alat peraga siswa dapat melihat, meraba, mengungkapkan dan memikirkan secara langsung obyek yang sedang dipelajari. Konsep abstrak yang disajikan dengan bantuan alat peraga akan dapat dipahami dan dimengerti serta dapat ditanamkan pada tingkat-tingkat yang lebih rendah.

Menurut Bruner (Bell, 1981, hal. 143) adalah baik bagi siswa untuk memulai dengan representasi konkret dari konsep, prinsip atau aturan yang ingin diformulasikan. Hal ini dikarenakan pada tahap awal belajar konsep, pemahaman bergantung pada aktivitas konkret yang siswa lakukan ketika mereka menyusun representasi dari masing-masing konsep tersebut. Hal senada dikemukakan juga oleh Dienes (Bell, 1981, hal. 142), bahwa setiap konsep atau prinsip matematika dapat dipahami lebih baik hanya jika pertama disajikan kepada siswa melalui beragam bentuk konkret yang merupakan representasi fisik dari konsep yang sedang dipelajari yang dalam hal ini adalah alat peraga.

(Ruseffendi, 1992,hal.140) menegaskan bahwa penggunaan alat peraga secara efektif membuat pelajaran matematika menjadi lebih menarik dan menyenangkan. (Shumway, 1980, hal. 377) juga menegaskan bahwa “...a 
significant number of students have poor attitude toward mathematics". Kegiatan pembelajaran dengan menggunakan alat peraga membuat siswa terlibat aktif, aktivitas mentalnya menjadi lebih meningkat sehingga membuat siswa semangat terhadap pembelajaran matematika dan siswa pun dapat mengkonstruksi pengetahuan dalam ranah kognitifnya. Oleh sebab itu pembelajaran matematika akan bermakna, tertarik dan siswa senang sehingga terhindar dari asumsi negatif siswa terhadap matematika.

Disamping itu, berdasarkan kurikulum 2013, pelaksanaan pembelajaran hendaknya menggunakan pendekatan saintifik, yang terdiri atas kegiatan observing (mengamati), questioning (menanya), associating (mengaitkan/menalar), experimenting (mencoba), dan networking (menjalin kerja sama/jejaring). Dengan demikian, penggunaan alat peraga hendaknya diawali dengan aktivitas yang meminta siswa mengamati masalah/kasus ataupun contoh dalam kehidupan sehari-hari, yang selanjutnya dikembangkan dan diselidiki dengan bantuan alat peraga.

Jelas terlihat bahwa alat peraga mempunyai peranan yang sangat penting dalam pembelajaran matematika. Berdasarkan uraian di atas, alat peraga matematika perlu digunakan oleh guru-guru dalam meningkatkan pemahaman siswa terhadap konsep-konsep matematika.

Selain itu, guru memiliki peranan penting dalam meningkatkan kualitas siswa dalam belajar matematika. Bukan saja dikarenakan alat peraga yang baik yang dapat meningkatkan pemahaman siswa tentang matematika, namun guru juga harus mampu menggunakan alat peraga yang sesuai dengan kontens materi pembelajaran yang akan diajarkan.
Namun kebanyakan guru menjadikan alat peraga sebagai alasan terakhir dalam proses belajar dan mengajar. Padahal seharusnya penggunaaan alat peraga adalah salah satu cara yang dapat meningkatkan pemahaman siswa terhadap setiap pembelajaran matematika.

Berdasarkan hasil penjajakan awal denga guru matematika di SMP Negeri 5 Langsa diperoleh informasi bahwa Sejauh ini guru telah menggunakan alat peraga matematika terbatas pada materi tertentu saja, karena alat peraga di sekolah relatif sedikit, sebagian besar alat peraga yang ada disekolah adalah disediakan oleh sekolah. Selain itu guru juga menggunakan alat peraga sederhana yang sudah dibuat sendiri dengan konsep yang sudah ada.

Menyahuti kondisi seperti dipaparkan di atas, penulis berinisiasi dan perlu menganalisis kemampuan guru dalam menggunakan alat peraga matematika di SMP/MTsN Kota Z Langsa. Adapun permasalahan yang harus dijawab dalam penelitian ini adalah bagaimanakah kemampuan guru matematika dalam menggunanakan alat peraga di SMP/MTsN Kota Langsa? Penelitian ini bertujuan untuk mengetahui kemampuan guru menggunakan alat peraga matematika di SMP Kota Langsa.

Kemampuan guru menggunakan alat peraga matematika dalam penelitian ini maksudnya adalah kemampuan guru menggunakan alat peraga yang terintegrasi dalam pembelajaran matematika sampai pada tahap-tahap abstrak atau tahap dimana alat peraga tidak digunakan lagi. 


\section{Metode Penelitian}

Peneliti mencoba menjelaskan, menggambarkan atau mendeskripsikan tentang kemampuan guru dalam menggunakan alat peraga matematika. Peneliti menggali informasi tentang kemampuan guru menggunakan alat peraga matematika dengan mewancarai guru dan mengobservasi kemudian menarasikan dengan kata-kata. Oleh sebab itu penelitian ini menggunakan metode penelitian deskriptif. Ditinjau dari jenis datanya, penelitian ini menggunakan pendekatan kualitatif.

Penelitian ini dilakukan di SMP Negeri 5 Langsa Aceh, Pengambilan data dilakukan pada tanggal 1 Agustus sampai dengan 5 Agustus 2018.

Data dalam penelitian ini adalah informasi atau data alat peraga dan data tentang kemampuan guru matematika menggunakan alat peraga matematika, sumber datanya adalah alat peraga dan guru matematika SMP Negeri 5 Langsa.

Teknik pengumpulan data yang digunakan adalah wawancara dan observasi. Peneliti mewawancari guru matematika untuk mengungkapkan informasi tentang alat peraga matematika dan kemampuan guru dalam memperagakan alat peraga matematika. Adapun indikator yang diwawancari adalah yaitu: kesediaan alat peraga matematika di sekolah, jenis alat peraga yang tersedia, kondisi alat peraga, penggunaan alat peraga dalam pembelajaran matematika dan kesulitannya, kesesuain alat peraga dengan materi dan tujuan pembelajaran, kemampuan siswa setelah menggunakan alat peraga, dan indiktor lain yang mengarah pada kemampuan guru menggunakan alat peraga.

Observasi dalam penelitian ini untuk mendapatkan data atau informasi tentang penggunaan alat peraga oleh guru matematika dalam pembelajaran matematika. Observasi dilakukan pada saat guru menggunakan alat peraga matematika yang terintegrasi dalam pembelajaran. Adapun indikator yang diamati pada saat penggunaan alat peraga oleh guru matematika adalah aspek keterkaitan alat peraga dengan materi, dan aspek aktivitas guru pada saat penggunaaan alat peraga yang terintegrasi dengan pembelajaran.

\section{Hasil Penelitian dan Pembahasan}

\section{Data Hasil Wawancara dan Dokumentasi}

Sebelum peneliti mendeskripsikan tentang kemampuan guru menggunakan alat peraga matematika di SMP/MTsN Kota Langsa, peneliti menggali informasi tentang ketersedian alat peraga disekolah, kondisi alat peraga disekolah dan informasi pendukung lainnya.

Berdasarkan hasil wawancara dengan guru matematika SMP Negeri 5 Langsa menunjukkan informasi yang relatif sama, yaitu guru tidak sering (kadang-kadang) menggunakan alat paraga dalam pembelajaran matematika, tidak semua materi matematika menggunakan alat peraga. Guru menggunakannya pada materi tertentu saja yang tersedia alat peraga disekolah, alat peraga yang digunakan guru dalam pembelajaran matematika seperti bangun ruang, alat peraga volume bangu ruang. Seperti yang diungkapkan oleh salah seorang guru matematika SMP Negeri 5 Langsa.

"Ya Kadang-kadang saja. Tidak semua materi saya pergunakan alat peraga, alat peraga disini sangat terbatas, kami hanya menggunakan alat peraga biasanya pada materi-materi bangun ruang, seperti kubus, balok, limas, prisma, kerucut, tabung, 
kerangka bangun ruang, ada juga alat peraga jaring-jaring bangun datar"

Selain menggunakan alat peraga yang disediakan disekolah, guru juga mengembangkan alat peraga lain dengan konsep-konsep yang sudah ada, guru membuat alat peraga praktis dan ekonomis dari lingkungan sekitar. Misalnya menggunakan "pipet" (silang yang digunakan untuk minum air) atau kertas karton dan kertas palstik tarnsparan tuk untuk materi pecahan, dan juga alat peraga kotak geser pemfaktoran yang terbuat busa warna-warni, sterefrom. Penjelasan tersebut seperti dikonfirmasi oleh guru matematika SMP Negeri 5 Langsa berikut ini.

"karena disekolah kekurangan alat peraga, jadi kadang saya juga membuat alat peraga praktis dan ekonomis dari lingkungan sekitar. Misalnya saya gunakan kertas kartun keras dan plastik trasnparan untuk mengajarkan materi pecahan". alat peraga saya buat terakhir ini adalah alat peraga kotak geser pemfaktoran"

Lebih lanjut guru menjelaskan bahwa alat peraga yang ada disekolah sebenarnya dalam kondisi baik, hanya saja kurang terawat. Karena disekolah tidak ada ruang khusus alat peraga. Selama ini alat peraga tersimpan di atas lemari di kantor guru, di perpustakaan, di ruang gudang.

\section{Hasil Wawancara tentang} Kemampuan guru menggunakan alat peraga

Data hasil wawancara dengan salah seorang guru SMP Negeri 5 Langsa diperoleh informasi bahwa langkah-langkah yang dilakukan guru dalam menggunakan alat peraga dalam pembelajaran adalah sebelumnya guru memilih alat peraga yang sesuai dengan materi, dalam pembelajaran guru memperkenalkan dulu alat peraga kepada siswa, guru menjelaskan dan memperagakan alat peraga di depan kelas, setelah siswa paham konsep yang diajarkan baru guru melanjutkan bahas soal.

"Awalnya saya pilih dulu alat peraga yang cocok dengan materinya, Saya coba perkenalkan dulu alat peraga kesiswa, saya coba jelaskan peragaannya, kemudian ya kadang saya suruh siswa memperagakan nya. Setelah siswa paham konsep baru saya lanjutkan dengan bahas soal “

Kemudian terkait dengan pola penggunaan alat peraga matematika di dalam kelas guru mendemonstrasikan alat peraga, kalau alat peraganya lebih dari satu maka guru mengajak siswa untuk membuat kelompok dan mamperagakan alat peraga perkelompok.

"Biasanya saya demonstrasikan atau pun kalau jumlahnya lebih ya saya buat kelompok. Jadi siswa juga ikut terlibat. Kalau secara individu siswa tidak tercover semuanya. Alat peraga sangat terbatas"

Adapun terkait dengan kesulitan menggunakan alat peraga, guru menjelaskan bahwa kesulitan sebenarnya terjadi karena ada kendala keterbatasan alat peraga yang ada disekolah. Akibatnya guru relatif sulit menentukan alat peraga lain yang cocok untuk suatu materi matematika, guru masih kesulitan memilih mana yang cocok dengan kompetensi dasar dan tujuan pembelajaran yang nantinya akan di ajarkan kepada siswa.

\section{Hasil Observasi Penggunaan Alat} Peraga Matematika yang Terintegrasi dalam Pembelajaran Matematika.

Untuk melihat keabsahan data hasil wawancara dengan guru dan untuk menggali informasi lebih detail tentang kemmpuan 
penggunaan alat peraga dalam pembelajaran matematika di kelas, peneliti melakukan observasi kemampuan guru dalam menggunakan alat peraga matematika yang terintegrasi dalam pembelajaran.

Observasi ini menggunakan instrumen observasi yang terdiri dari beberapa aspek penilaian tentang penggunaan alat peraga matematika yang terintegrasi dalam pembelajaran.

Observasi dilakukan di kelas IX SMP 5 Langsa pada materi persamaan kuadrat, berdasarkan diskusi guru kelas diperoleh informasi bahwa kelas yang akan diobservasi adalah kelas IX yang menerapkan kurikulum 2013. Indikator aktivitas guru terkait penggunaan alat peraga yang terintegrasi dalam pembelajaran yang diperhatikan untuk diamati adalah dibuat berdasarkan apa yang dikatakan oleh (Johar, 2013) bahwa penggunaan alat peraga hendaknya diawali dengan aktivitas yang meminta siswa mengamati. Hal ini diperlukan karena pelaksanaan pembelajaran menurut kurikulum 2013 hendaknya menggunakan pendekatan saintifik, yang terdiri atas kegiatan observation (mengamati), questioning (menanya), associating (mengaitkan/menalar), experimenting (mencoba), dan networking (menjalin kerja sama/jejaring). Berdasarkan penjelasan di atas, peneliti telah membuat indikator penggunaan alat peraga terintegrasi dalam pembelajaran matematika. Adapun indikator dan hasil observasi aktivitas guru terkait penggunaan alat peraga dalam pembelajaran matematika, yaitu
Tabel Observasi Penggunaan Alat Peraga yang Terintegrasi Pembelajaran Matematika SMP Negeri 5 Langsa Kelas IX

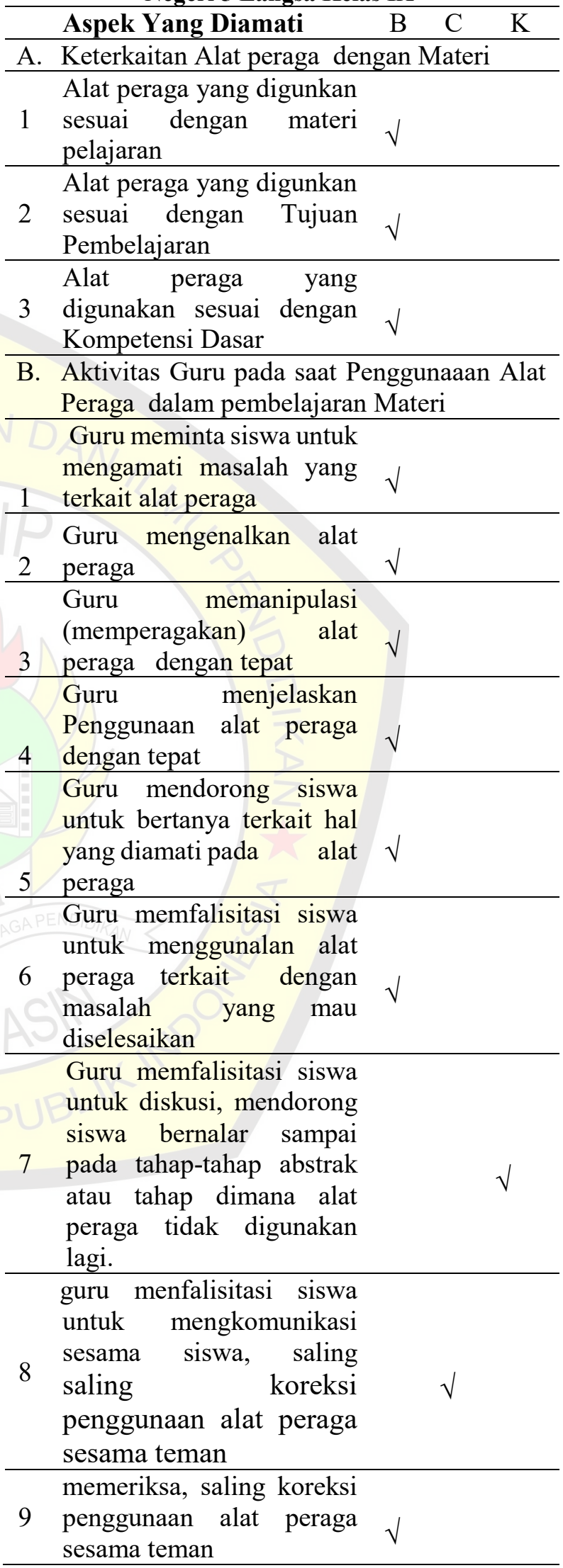


Berdasarkan hasil observasi alat peraga kotak geser pemfaktoran menunjukkan bahwa alat peraga kotak geser pemfaktoran terkait dengan baik dengan materi, tujuan pembelajaran, dan kompetensi dasar. Alat peraga kotak geser pemfaktoran digunakan pada materi persamaan kuadrat kelas IX SMP Kurikulum 2013. Alat peraga ini juga sejalan dengan tujuan dan Kompetensi dasar pada Kurikulum 2013, yaitu tujuannya untuk menentukan akar persamaan kuadrat dengan memfaktorkan. Sedangkan kompetensi dasar adalah menjelaskan persamaan kuadrat dan karakteristiknya berdasarkan akar-akarnya serta cara penyelesaiannya, dengan kata lain alat peraga ini membantu siswa untuk memudahan melakukan pemfaktoran persamaan kuadrat sehingga siswa bisa mencari akar-akarnya.

Kemudian lebih lanjut, hasil observasi pada aspek B, yaitu aktivitas guru pada saat penggunaan alat peraga dalam pembelajaran Matematika menunjukkan bahwa semua aspek yang diamati (1), (2), (3), (4), (5), (6), (7), (8) dan (9) pada pembelajaran sudah dilakukan guru. Guru merancang pembelajaran berbantuan alat peraga sampai pada konsep matematika bersifat abstrak. Guru mengajak siswa untuk mengamati persamaan kuadrat dan faktornya, selanjutnya guru mengenalkan alat peraga kotak geser pemfaktoran, memperagakan alat peraga disertai dengan penjelasannya, menanggapi pertanyaan siswa terkait penggunaan alat peraga kotak geser, memfalisitasi siswa menjawab soal dengan bantuan alat peraga, dan juga memfalisitasi siswa untuk berdiskusi. Walaupun pada keseluruhannya penggunaan alat peraga sudah baik, namun pada aspek (7) yaitu guru memfalisitasi siswa untuk diskusi, mendorong siswa bernalar sampai pada tahap-tahap abstark atau tahap dimana alat peraga tidak digunakan lagi, masih belum terpenuhi. Tidak terlihat guru menggunakan alat peraga kotak geser pemfaktoran sampai pada tahap-tahap abstark atau tahap dimana alat peraga tidak digunakan lagi.

Seharusnya yang harus dilakukan guru lagi pada kegiatan lebih lanjut adalah siswa didorong untuk tidak menggunakan lagi kotak geser, tetapi cukup menggambarkan dan seterusnya siswa tinggal menggunakan tekniknya saja. Hal ini sejalan apa yang ditemukan oleh (Johar, 2003) bahwa guru hanya menggunakan alat peraga untuk membuka pelajaran namun tidak sampai pada konsep ataupun rumus matematika yang dipelajari. Lebih lanjut (Johar, 2003) memberikan contoh "untuk mengenalkan konsep gradien guru menunjukkan alat peraga kayu yang disandarkan pada dinding, atau pegangan pada tangan. Namun, setelah itu guru melupakan alat peraga langsung menuliskan rumus gradien melalui dua titik".

Berdasarkan hasil observasi guru pada saat penggunaan alat peraga kotak geser pemfaktoran sebenarnya sudah relatif cukup baik meskipun ada yang kurang karena tidak sampai pada abstrak. Alat peraga kotak geser pemfaktoran digunakan untuk memudahkan pemfaktoran sehingga siswa terbantu pada saat pemfaktoran.

\section{Simpulan dan Saran}

\section{Kesimpulan}

Kemampuan guru menggunakan alat peraga belum optimal, indikasinya adalah setelah menggunakan alat peraga guru tidak sampai pada konsep ataupun rumus matematika yang dipelajari. Berdasarkan hasil wawancara tidak diperoleh informasi secara detail bahwa guru menggunakan alat peraga sampai pada tahap rumus matematika yang 
dipelajari. Guru menjawab pertanyaan peneliti secara umum tentang penggunaan alat peraga. Informasi/data konfirmasi terkait guru menggunakan alat peraga tidak sampai pada tahap konsep/ rumus matematika yang dipelajari diperoleh dari hasil observasi yang menunjukkan bahwa guru menggunakan alat peraga kotak geser pemfaktoran tidak sampai pada tahap-tahap abstak atau tahap dimana alat peraga tersebut tidak digunakan lagi. Berdasarkan hasil observasi, setelah guru menggunakan alat peraga kotak geser pemfaktoran, guru tidak mendorong siswa untuk tidak menggunakan lagi kotak geser, atau guru tidak menyuruh siswa cukup menggambarkan dan seterusnya siswa tinggal menggunakan tekniknya saja untuk menyelesaikan pemfaktoran.

\section{Saran}

Hasil penelitian ini dapat dijadikan dasar untuk penelitian atau pelatihan perancangan dan penggunaan alat peraga matematika. Khusus untuk guru disarankan untuk terus meningkatkan kemampuan menggunakan alat peraga matematika. Dosen hendaknya terus meningkatkan kemampuan mahasiswa sebagai calon guru matematika untuk merancang dan meningkatkan kemampuan menggunakan alat peraga matematika.

\section{Daftar Pustaka}

Bell, F.H. (1981). Teaching and learning mathematics (in secondary schools). Iowa: Wm. C. Brown Company.

Johar, Rahmah. (2013). Alat Peraga Matematika. Makalah disampaikan pada
Seminar Alat Peraga. STAIN Malikussaleh, tanggal 23 September 2013

Muijs, D., \& Reynolds, D. (2005). Effective teaching evidence and practice. London: SAGE Publications.

Pujiati. (Oktober 2004). Penggunaan alat peraga dalam pembelajaran matematika SMP. Makalah disajikan pada Diklat Instruktur/Pengembangan Matematika SMP Jenjang Dasar, di PPPG Matematika Yogyakarta.

Ruseffendi, E.T. (1992). Materi pokok pendidikan matematika 3. Jakarta: Departemen Pendidikan dan Kebudayaan Proyek Pembinaan Tenaga Kependidikan Pendidikan Tinggi. 